HYPOTHESIS

\title{
Age related shift in the mutation spectra of germline and somatic NF2 mutations: hypothetical role of DNA repair mechanisms
}

\author{
D G R Evans, E R Maher, M E Baser
}

J Med Genet 2005;42:630-632. doi: 10.1136/jmg.2004.027953

It has been suggested that somatic mutations that accumulate due to an age related decline in the efficiency of DNA repair mechanisms might contribute to the increased incidence of cancer in older people. However, there is little direct evidence for this phenomenon. The spectra of germline and somatic mutations can be compared in cancer genes that cause inherited tumour syndromes and sporadic tumours, respectively. In addition, mosaic patients reflect the nature of mutations that occur in early development. Hence, we hypothesised that the "temporal mutation record" of a human cancer gene might provide insight into mechanisms of mutagenesis in the germline, in early development, and in adulthood. We compared the ratio of frameshift to nonsense mutations in three diseases that are related to the NF2 tumour suppressor gene: classic neurofibromatosis 2 (NF2), caused by germline NF2 mutations; mosaic NF2; and unilateral sporadic vestibular schwannoma (USVS), caused by somatic NF2 inactivation. Nonsense mutations predominated in both classic and mosaic NF2, but the ratio of nonsense to frameshift mutations was reversed in USVS. Moreover, in USVS patients, the ratio of somatic frameshift to nonsense mutations increased significantly with increasing age at diagnosis. This pattern is consistent with an age related decline in the efficiency of DNA repair mechanisms. Similar studies for other familial cancer genes may provide further evidence for this hypothesis.

See end of article for authors' affiliations

Correspondence to:

Dr M E Baser, 10622

Kinnard Avenue, 203, Los Angeles, CA 90024, USA; michael.baser@verizon. net

Received 6 October 2004 Revised

23 November 2004

Accepted

23 November 2004
M utations in the human genome occur during spermatogenesis and oogenesis (meiosis) or during somatic growth and replication (mitosis). Inherited cancer syndromes are usually caused by mutations that occur during meiosis, while sporadic tumours are typically caused by somatic mutations and epigenetic events. Some cancer susceptibility genes cause both familial and sporadic cancers, and in these genes, comparisons of the germline and somatic mutational spectra have provided important insights into mechanisms of mutagenesis and tumorigenesis.

Germline mutations in the VHL gene cause von Hippel-Lindau disease, and somatic $V H L$ mutations occur in most sporadic renal cell carcinomas. VHL mutations that are predicted to produce a truncated protein account for $78 \%$ of somatic mutations, but for only $37 \%$ of germline mutations. ${ }^{1}$ VHL families with germline truncating mutations have a higher frequency of renal cell carcinoma than families with missense mutations, ${ }^{1}$ suggesting that the preponderance of somatic truncating mutations in sporadic renal cell carcinoma reflects selection during tumorigenesis.

The TP53 gene is unusual for the high frequency of missense mutations. There are common mutation hotspots in the spectra of germline and somatic TP53 mutations, and there are also somatic mutation hotspots in specific tumour types. ${ }^{2}$ In contrast, the germline and somatic mutation spectra of the NFI tumour suppressor gene are similar in types and frequencies of mutations. ${ }^{3}$

There are non-random associations between the type of first and second hits in germline and somatic APC tumour suppressor gene mutations in people with familial adenomatous polyposis and sporadic colorectal cancer, respectively. ${ }^{4}$ APC mutations in the "mutation cluster region", around codon 1300, are associated with loss of the second APC allele, whereas tumours with mutations outside this region tend to have a second truncating mutation. The causes of this phenomenon have been hypothesised to be selection for retained $\mathrm{N}$ terminal and lost $\mathrm{C}$ terminal APC functions, effects on beta-catenin levels, and APC protein stability. ${ }^{5}$

Neurofibromatosis 2 (NF2) is an autosomal dominant disorder caused by inactivating mutations in the NF2 tumour suppressor gene. NF2 is characterised by nervous system tumours such as schwannomas and meningiomas. Consistent with the Knudsen two hit hypothesis, the germline NF2 allele is inactivated and tumours occur when the wildtype NF2 allele is inactivated by mutation, silencing, or allelic loss. Unilateral sporadic vestibular schwannoma (USVS) also has somatic biallelic NF2 inactivation.

There is a high prevalence of mosaicism in NF2 (up to $30 \%$ of people with new mutations). ${ }^{6}$ This is not the case in other familial cancer syndromes such as familial adenomatous polyposis (FAP) and $\mathrm{VHL}^{7}$ although it is possible that some patients with colorectal cancer or renal cell carcinoma could be mosaics who do not fulfil

Abbreviations: FAP, familial adenomatous polyposis; NF2, neurofibromatosis 2; USVS, unilateral sporadic vestibular schwannoma 
clinical diagnostic criteria for FAP or VHL. Mosaicism occurs in many genetic diseases, but there is little information on the likely mechanism of mutagenesis. Hence, NF2 provides an opportunity to determine if there is evidence for age related changes in mutation mechanisms by comparing NF2 mutation spectra in classic (non-mosaic) NF2, in mosaic NF2, and in USVS. Classic NF2 refers to people who meet the Manchester clinical diagnostic criteria for NF2. ${ }^{8}$

In this study, we used an international database of germline and somatic NF2 mutations to compare the distributions of germline and somatic truncating NF2 mutations (nonsense and frameshift mutations). ${ }^{9}$ In classic NF2, germline non-truncating NF2 mutations cause milder disease than truncating mutations. ${ }^{10}$ This would cause selection for truncating mutations in USVS if partial protein function caused by a missense mutation decreases Schwann cell proliferation and lessens the chance of inducing a second "hit" in the NF2 gene. Indeed, NF2 missense mutations were more common in the germline (34 of 562 family mutations; $6.0 \%$ ) than in USVS (4 of 226 tumours; $1.8 \%) \quad(p=0.009)$. This is consistent with the mild phenotypic effect of missense mutations in NF2 and the lower likelihood of these mutations being expressed in somatic form, as occurs in VHL. We did not include NF2 large deletions in this study because it is not possible to determine the true prevalence of NF2 large deletions as opposed to loss of the entire chromosome 22 in most reports of NF2 related sporadic tumours, and because identifying large NF2 deletions is more difficult in mosaics than in the germline. ${ }^{6}$

The distributions of nonsense and frameshift NF2 mutations for classic NF3 and mosaic NF2 and USVS are shown in table 1. Nonsense mutations were more common than frameshift mutations in classic NF2 and in mosaics, but the converse was true in USVS (Fisher's exact test, p<0.001). Nonsense and frameshift mutations are each predicted to produce truncated proteins, so it is likely that these differences reflect different mechanisms of mutagenesis rather than selection during sporadic tumorigenesis. The predominance of nonsense mutations in classic NF3 and in mosaic NF2 suggests that there are similar mechanisms of mutagenesis during meiosis and early embryonic development. The precise timing of mutations that occur in mosaic NF2 cannot be assessed, but at least half of the mosaic NF2 mutations reported to date have not been identified in blood and therefore are probably present in $<10 \%$ of cells. We did not find differences in mutation spectra between patients with a detectable mutation in blood and neural crest cells (that is, mutations that occurred early in development) and patients in whom the mutation was present in tumours but not in blood (that is, mutations that could have occurred after differentiation from toti potential cells in the neural crest).

Nonsense NF2 mutations occur primarily at CpG dinucleotides. The NF2 gene has six CpG sites in exons $1-15$ in which nonsense mutations predominate. There is another $\mathrm{CpG}$ site in exon 16, but pathogenic NF2 mutations have not been reported in exons 16 or 17. In the international NF2 mutation database, 102 (53\%) of 193 constitutional nonsense NF2 mutations occur in the six CpG sites. This proportion is similar for USVS: 19 (45\%) of 42 somatic nonsense NF2 mutations occur in the six $\mathrm{CpG}$ sites. This indicates that $\mathrm{CpG}$ methylation is a risk factor for NF2 nonsense mutations during gametogenesis and post-zygotically. CpG dinucleotides are hypermutable, ${ }^{11}$ particularly when there is a flanking pyrimidine residue. ${ }^{12}$ Five of the six NF2 CpG sites are flanked by a pyrimidine residue, which may explain the high ratio of nonsense mutations in NF2 compared to other tumour prone disorders such as adenomatous polyposis coli.
Table 1 Mutation spectra in NF2 related conditions

\begin{tabular}{|c|c|c|c|c|}
\hline \multirow[b]{2}{*}{ Condition } & \multicolumn{2}{|c|}{ Nonsense mutation } & \multicolumn{2}{|c|}{ Frameshift mutation } \\
\hline & No. & $\begin{array}{l}\% \text { of } \\
\text { total }\end{array}$ & No. & $\begin{array}{l}\% \text { of } \\
\text { total }\end{array}$ \\
\hline Classic NF2 & 191 & 57 & 145 & 43 \\
\hline Mosaic NF2 & 39 & 62 & 24 & 38 \\
\hline All USVS* & 42 & 24 & 130 & 76 \\
\hline $\begin{array}{l}\text { USVS diagnosed at } \\
\text { ages }<40 \text { years }\end{array}$ & 13 & 52 & 12 & 48 \\
\hline $\begin{array}{l}\text { USVS diagnosed at } \\
\text { ages } \geqslant 40 \text { years }\end{array}$ & 18 & 23 & 61 & 77 \\
\hline \multicolumn{5}{|c|}{$\begin{array}{l}\text { USVS, unilateral sporadic vestibular schwannoma. *Of the } 172 \text { USVS } \\
\text { patients, } 104 \text { had information on age at diagnosis. The age of } 40 \text { years } \\
\text { was chosen to define USVS age categories because USVS typically occur } \\
\text { after this age. }{ }^{23} \text { Difference in proportion of frameshift in classic NF2 or } \\
\text { mosaic NF2 compared to USVS, Fisher's exact test, } p<0.001 \text {; difference } \\
\text { in proportion of frameshift mutations between age categories in USVS, } \\
\text { Fisher's exact test, } p=0.011 \text {. }\end{array}$} \\
\hline
\end{tabular}

The mutability of $\mathrm{CpG}$ sites has been attributed to frequent methylation of cytosine, which results in deamination.

Methylation is required in the early embryo and occurs at CpG sites. ${ }^{13}$ Methylation at CpG sites increases the risk of mutation, and inactivation of Dnmtl in embryonic stem cells reduces overall mutation rates, although this has not been demonstrated in CpG sites. ${ }^{14}$ The relative paucity of somatic nonsense mutations in USVS could be due to a lower absolute rate of mutagenesis at $\mathrm{CpG}$ dinucleotides, as might be predicted if demethylation occurred, or to a higher absolute frequency of frameshift mutations with increasing age. The age related methylation status of intragenic NF2 $\mathrm{CpG}$ sites has not been defined, but $\mathrm{CpG}$ promoter region methylation occurs in a subset of USVS, ${ }^{15}$ suggesting that there is not a general tendency for NF2 genomic demethylation with increasing age. Indeed, hypermethylation of the promoter region as a cause of tumours appears to increase with increasing age. ${ }^{16} 17$

To further investigate age related changes in NF2 mutations, we evaluated the NF2 mutation spectra in USVS patients with increasing age at diagnosis. The proportion of frameshift to nonsense mutations was significantly greater in older than in younger USVS patients (table 1). Using logistic regression, the ratio of frameshift to nonsense mutations increased 1.03 fold per year of age $(p=0.040)$.

The higher proportion of frameshift NF2 mutations in older USVS patients might result from an increased rate of mutagenesis or from reduced mutation repair efficiency. To date, specific environmental risk factors for USVS have not been identified. In particular, chemical mutagens that cause frameshift mutations (for example, DNA intercalating agents such as ethidium bromide) have not been implicated in the pathogenesis of USVS. Hence, the most likely explanation for the results of this study may be an age related reduction in DNA repair efficiency. ${ }^{18}$ In colorectal cancer, somatic inactivation of the $\mathrm{MLHl}$ mismatch repair gene by promoter methylation is associated with advanced age. ${ }^{19} \mathrm{Mlhl}$ inactivation results in susceptibility to somatic apc truncating mutations, most of which are frameshift mutations. ${ }^{20}$ However, USVS is not a feature of hereditary non-polyposis colon cancer syndrome, and microsatellite instability is infrequent in USVS, so there is no direct evidence to implicate deficient mismatch repair gene activity in the age related preponderance of frameshift mutations in USVS.

Vestibular schwannoma is not a feature of other known inherited DNA repair defect syndromes. However, there is experimental evidence for an age related decline in other DNA repair mechanisms. An age associated decline in base excision repair mechanisms has been reported in rodents and 
in human skin,, ${ }^{21-24}$ and a reporter transgene has a higher mutation rate in older animals. ${ }^{25}$ Sedelnikova et $^{2 l^{26}}$ suggested that aging cells may accumulate irreparable DNA double strand breaks, and it has been suggested that older animals preferentially accumulate large genomic rearrangements. ${ }^{27}$ The observation that DNA end joining is less efficient and more error prone in senescent cells suggests that an age related impairment of non-homologous end joining might facilitate genomic rearrangements and deletions, and lead to an increased incidence of cancer in the elderly. ${ }^{28}$

The incidence of USVS increases exponentially with increasing age in adults. ${ }^{29}$ Biallelic NF2 inactivation in USVS arises through a two step process, and large deletions of chromosome 22 are the most common second event. Hence, the age related increase in the incidence of USVS could result from an increased susceptibility to frameshift mutations and genomic rearrangements in senescent cells. Repair mechanisms for frameshift mutations may become less efficient with increasing age than repair mechanisms for nonsense mutations, or age related mutagenesis may be more likely to generate frameshift mutations than nonsense mutations.

An age related accumulation of somatic mutations has been frequently implicated as the cause of the increased incidence of cancer in the elderly, but to our knowledge, NF2 provides the first example of an age related shift in mutation pattern in humans. Similar findings for other human cancer genes would strengthen the case for a role of age related changes in genomic stability and the efficiency of DNA repair mechanisms in the pathogenesis of increased cancer risk in old age, and could uncover evidence for specific environmental mutagens in some groups of patients. ${ }^{30}$

\section{ACKNOWLEDGEMENTS}

We thank A Wilkie and B Kysela for their helpful discussions.

\section{Authors' affiliations}

D G R Evans, University Department of Medical Genetics, St. Mary's Hospital, Manchester M13 OJH, UK

E R Maher, Section of Medical and Molecular Genetics, University of Birmingham School of Medicine, Birmingham B15 2TT, UK

M E Baser, Los Angeles, CA, 90024 USA

Competing interests: none declared

\section{REFERENCES}

1 Gallou C, Joly D, Méjean A, Staroz F, Martin N, Tarlet G, Orfanelli MT, Bouvier R, Droz D, Chrétien Y, Maréchal JM, Richard S, Junien C, Béroud C. Mutations of the $\mathrm{VHL}$ gene in sporadic renal cell carcinoma: definition of a risk factor for VHL patients to develop an RCC. Hum Mutat 1999;13:464-75.

2 Glazko GV, Koonin EV, Rogozin IB. Mutation hotspots in the p53 gene in tumors of different origin: correlation with evolutionary conservation and signs of positive selection. Biochem Biophys Acta 2004;1679:95-106.

3 Upadhyaya M, Han S, Consoli C, Majounie E, Horan M, Thomas NS, Potts C, Griffiths S, Ruggieri M, von Deimling A, Cooper DN. Characterization of the somatic mutational spectrum of the neurofibromatosis type 1 (NF1) gene in neurofibromatosis patients with benign and malignant tumors. Hum Mutat 2004;23:134-46.

4 Lamlum H, llyas M, Rowan A, Clark S, Johnson V, Bell J, Frayling I, Efstathiou J, Pack K, Payne S, Roylance R, Gorman P, Sheer D, Neale K, Phillips R, Talbot I, Bodmer W, Tomlinson I. The type of somatic mutations at APC in familial adenomatous polyposis is determined by the site of the germline mutation: a new facet to Knudson's "two-hit" hypothesis. Nat Med 1999:5:1071-5.

5 Crabtree M, Sieber OM, Lipton L, Hodgson SV, Lamlum H, Thomas HJW, Neale K, Phillips RKS, Heinimann K, Tomlinson IPM. Refining the relation between "first hits" and "second hits" at the APC locus: the "loose fit" model and evidence for differences in somatic mutation spectra among patients. Oncogene 2003;22:4257-65.

6 Moyhuddin A, Baser ME, Watson C, Purcell S, Ramsden RT, Heiberg A, Wallace AJ, Evans DGR. Somatic mosaicism in neurofibromatosis 2: prevalence and risk of disease transmission to offspring. J Med Genet 2003:40:459-63

7 Sgambati MT, Stolle C, Choyke PL, Walther MM, Zbar B, Linehan WM, Glenn GM. Mosaicism in von Hippel-Lindau disease: lessons from kindreds with germline mutations identified in offspring with mosaic parents. Am J Hum Genet 2000;66:84-91.

8 Evans DGR, Huson SM, Donnai D, Neary W, Blair V, Newton V, Harris R. A clinical study of type 2 neurofibromatosis. Q J Med 1992;84:603-18.

9 Baser ME. Neurofibromatosis 2 (NF2) mutation databases. Human Gene Mutation Database 2004. Available at: http://uwcmml1s.uwmc.ac.uk/ $\mathrm{uwcm} / \mathrm{mg} / \mathrm{nf} 2$

10 Baser ME, Kuramoto L, Joe H, Friedman JM, Wallace AJ, Gillespie JE, Ramsden RT, Evans DGR. Genotype-phenotype correlations for nervous system tumor in neurofibromatosis 2: a population-based study. Am J Hum Genet 2004; 75:231-9.

11 Kondrashov AS. Direct estimates of human per nucleotide mutation rates at 20 loci causing mendelian diseases. Hum Mutat 2003;21:12-27.

12 Ikehata H, Takatsu M, Saito Y, Ono T. Distribution of spontaneous CpGassociated $\mathrm{G}: \mathrm{C} \rightarrow \mathrm{A}: \mathrm{T}$ mutations in the lacZ gene of Muta mice: effects of $\mathrm{CpG}$ methylation, the sequence context of $\mathrm{CpG}$ sites, and severity of mutations on the activity of the lacZ gene product. Environ Mol Mutagen 2000;36:301-11.

13 Dodge JE, Ramsahoye BH, Wo ZG, Okano M, Li E. De novo methylation of MMLV provirus in embryonic stem cell CpG versus non-CpG methylation. Gene 2002;289:41-8.

14 Chan MF, van Amerongen R, Niijar T, Cuppen E, Jones PA, Laird PW. Reduced rates of gene loss, gene silencing, and gene mutation in Dnmtdeficient embryonic stem cells. Mol Cell Biol 2001;21:7587-600.

15 Kino T, Takeshima H, Nakao M, Nishi T, Yamamoto K, Kimura T, Saito Y, Kochi M, Kuratsu J-i, Saya H, Ushio Y. Identification of the cis-acting region in the NF2 gene promoter as a potential target for mutation and methylationdependent silencing in schwannoma. Genes Cells 2001;6:441-54.

16 Kondo Y, Issa JP. Epigenetic changes in colorectal cancer. Cancer Metastasis Rev 2004;23:29-39.

17 Li LC, Shiina H, Deguchi M, Zhao H, Okino ST, Kane CJ, Carroll PR, Igawa M, Dahiya R. Age-dependent methylation of ESR1 gene in prostate cancer. Biochem Biophys Res Commun 2004;321:455-61.

18 Lee D-H, O'Connor TR, Pfeifer GP. Oxidative DNA damage induced by copper and hydrogen peroxide promotes $C G \rightarrow \Pi$ tandem mutations at methylated CpG dinucleotides in nucleotide excision repair-deficient cells. Nucleic Acids Res 2002;30:3566-73.

19 Nakagawa H, Nuovo GJ, Zervos EE, Martin EW Jr, Salovaara R, Aaltonen LA, de la Chapelle A. Age-related hypermethylation of the 5' region of $\mathrm{MLH} 1$ in colonic mucosa is associated with microsatellite-unstable colorectal cancer development. Cancer Res 2001;61:6991-5.

20 Vega A, Sobrido MJ, Ruiz-Ponte C, Barros F, Carracedo A. Rare HRAS1 alleles are a risk factor for the development of brain tumors. Cancer 2001;92:2920-6.

21 Xu G, Snellman E, Bykov VJ, Jansen CT, Hemminki K. Effect of age on the formation and repair of UV photoproducts in human skin in situ. Mutat Res 2000;459:195-202

22 Rao KS, Annapurna VV, Raji NS. DNA polymerase-beta may be the main player for defective DNA repair in aging rat neurons. Ann NY Acad Sci 2001;928:113-20

23 Cabelof DC, Raffoul JJ, Yanamadala S, Ganir CX, Guo Z, Heydari AR. Attenuation of DNA polymeriase beta-dependant base excision repair and increased DMA-induced mutagenicity in aged mice. Mutat Res 2002;500:135-45

24 Intano GW, McMahan CA, McCarrey JR, Walter RB, McKenna AR, Matsumoto $Y$, Maclnnes MA, Chen DJ, Walter CA. Base excision repair is limited by different proteins in male germ cell nuclear extracts prepared from young and old mice. Mol Cell Biol 2002;22:2410-18.

25 Stuart GR, Glickman BW. Through a glass, darkly: reflections of mutation from lacl transgenic mice. Genetics 2000;155:1359-67.

26 Sedelnikova OA, Horikawa I, Zimonjic DB, Pepescu NC, Bonner WM, Barret JC. Senescing human cells and ageing mice accumulate DNA lesions and unrepairable double-strand breaks. Nat Cell Biol 2004;6:168-70.

$27 \mathrm{Viig} \mathrm{J,} \mathrm{Dolle} \mathrm{ME.} \mathrm{Large} \mathrm{genome} \mathrm{rearrangements} \mathrm{as} \mathrm{a} \mathrm{primary} \mathrm{cause} \mathrm{of} \mathrm{aging}$ Mech Ageing Dev 2002;123:907-15

28 Seluanov A, Mittelman D, Pereira-Smith OM, Wilson JH, Gorbunova V. DNA end joining becomes less efficient and more error-prone during cellular senescence. Proc Natl Acad Sci USA 2004;101:7624-9.

29 Howitz MF, Johansen C, Tos M, Charabi S, Olsen JH. Incidence of vestibular schwannoma in Denmark, 1977-1995. Am J Otol 2000;21:690-4.

30 Bruning T, Weirich G, Hornauer MA, Hofler H, Brauch H. Renal cell carcinomas in trichloroethene (TRI)-exposed persons are associated with somatic mutations in the von Hippel-Lindau (VHL) tumour suppressor gene. Arch Toxicol 1997:71:332-5. 